\title{
Imaginário e envelhecimento: imagens simbólicas de três nonagenários ${ }^{1}$
}

\author{
Walter José Martins Migliorini² \\ Universidade Estadual Paulista Júlio de Mesquita Filho, Araraquara-SP, Brasil
}

\begin{abstract}
Resumo: Ensaio de hermenêutica sobre as imagens simbólicas de nonagenários com a finalidade de investigar as estruturas do imaginário prevalentes e suas organizações psíquicas. Por meio de entrevistas semanais abertas, foram coligidas estórias, grafismos, sonhos, devaneios e lembranças dos anciões. O material foi analisado analisado segundo a teoria do imaginário de Gilbert Durand, que propõe uma interpretação não pulsional do símbolo. Os critérios de amostragem foram: faixa etária acima de 90 anos, ausência de um quadro de demência senil arteriosclerótica (serem clinicamente saudáveis), atividade social e participação voluntária. Os resultados indicam ausência de uma estrutura do imaginário recorrente, presença de uma exuberante imaginação simbólica, permeabilidade entre conteúdos da memória e imaginação, além de criatividade e vívidos processos afetivos.
\end{abstract}

Palavras-chave: imaginação, imaginário, símbolo, envelhecimento, gerontologia.

\section{Imagery and aging: the symbolic images of three nonagenarians}

\begin{abstract}
This is a hermeneutic essay on the symbolic images of nonagenarians aimed to investigate the prevailing structures of their imagery and psychic organization. Stories, drawings, dreams, reveries and memories were collected during weekly open interviews and analyzed according to the Theory of Structures of Imaginary by Gilbert Durand, who proposes a nondrive-based interpretation of symbols. The sampling criteria were: people older than ninety years, absence of arteriosclerotic senile dementia (being clinically healthy), social activity and voluntary participation. The results revealed the absence of a recurrent structure of imaginary, an exuberant symbolical imagination, permeability through contents related to memory and imagination in addition to creativity and vivid affective processes.
\end{abstract}

Keywords: imagination, imaginary, symbol, aging, gerontology.

\section{Imaginario y envejecimiento: las imágenes simbólicas de tres nonagenarios}

Resumen: Estudio de hermenéutica acerca las imágenes simbólicas de nonagenarios que objetiva, investigar las estructuras del imaginario prevalentes y sus organizaciones psíquicas. A través de entrevistas semanales abiertas han sido aunados, histórias, grafismos, sueños, devaneos y recuerdos de los ancianos, analizados, según la teoría del imaginario de Gilbert Durand, que plantea una interpretación no pulsional del símbolo. Los criterios de muestreo han sido: rango de edad sobre los noventa años, ausencia de un cuadro de demencia senil arteriosclerótica (sean clinicamente sanos), actividad social y participación voluntaria. Los resultados demuestran la ausencia de uma estructura de imaginário recurrente, la presencia de una copiosa imaginación simbólica, la permeabilidad entre contenidos de la memoria y imaginación, además de creatividad y procesos afectivos vividos.

Palabras clave: imaginación, imaginario, símbolo, envejecimiento, gerontologia.

A imaginação simbólica tem sido pouco explorada e valorizada nas investigações sobre o envelhecimento, enquanto a memória tem sido privilegiada, possivelmente, por seu papel fundamental na sobrevivência e adaptação e por ser uma das funções psíquicas mais valorizadas culturalmente. A Psicologia Analítica fez uma importante contribuição sobre o papel da imagem simbólica no desenvolvimento emocional na maturidade (Jung, 1973), mas encontra um limite na seguinte questão: seriam as interpretações baseadas nas

1 Apoio: CNPq. O autor agradece aos anciões que generosamente participaram desse estudo, a colaboração fundamental da Prof. Dra. Altair Macedo Lahud Loureiro, o incentivo da Prof. Dra. Maria Cecília Sanchez Teixeira e o trabalho de revisão do texto realizado por Leonardo Dalla Valle. Este artigo é derivado da Tese de Doutorado defendida pelo autor, junto ao Programa de Pós-graduação em Psicologia Clínica do Instituto de Psicologia da Universidade de São Paulo, São Paulo, SP.

2 Endereço para correspondência:

Prof. Dr. Walter José Martins Migliorini. Universidade Estadual Paulista Júlio de Mesquita Filho. Faculdade de Ciências e Letras de Araraquara. Departamento de Psicologia da Educação. Rodovia Araraquara-Jaú, Km 1. CEP 14.800-901. Araraquara-SP, Brasil. E-mail: walter@fclar.unesp.br hermenêuticas que têm como chave a pulsão as mais apropriadas para abordar o imaginário da velhice? Pulsão é o termo empregado originalmente por Freud (1905/2002) para acentuar o caráter de plasticidade e polimorfismo característico da sexualidade humana em contraposição ao termo instinto da Biologia, que implica regularidade e universalidade do comportamento. Uma interpretação pulsional é aquela que tem como chave hermenêutica uma determinada pulsão, seja esta a sexualidade, a destrutividade ou a criatividade.

O presente estudo é um ensaio de hermenêutica sobre a imaginação simbólica na velhice, no qual será aplicado o método de interpretação criado por Gilbert Durand (1980/1989) na análise das imagens simbólicas produzidas por três anciões nonagenários. A finalidade é investigar as estruturas do imaginário prevalentes, assim como suas organizações psíquicas.

\section{A imagem simbólica}

A imagem simbólica, ou seja, aquela que não depende diretamente da senso-percepção, parece ser refratária a 
qualquer objetividade explicativa categórica ou universal e, simultaneamente, permeável aos mais distintos métodos de interpretação. As diversas escolas psicanalíticas, por exemplo, podem ser classificadas através do tipo de pulsão que priorizam no momento da interpretação. Tornou-se necessária, atualmente, uma nova compreensão dessas hermenêuticas e uma revisão da concepção pulsional do símbolo. A Filosofia, a Antropologia e os avanços da pesquisa clínica sobre a imagem, vêm fornecendo elementos para essa nova compreensão.

A evolução das idéias a respeito da imagem mental é, segundo Piaget e Inhelder (1963/1969), “talvez aquilo que marca mais claramente as etapas da psicologia experimental". p. 318 Nesse sentido, eles distinguem três períodos fundamentais no desenvolvimento do conceito de imagem. Ao primeiro e segundo períodos correspondem, respectivamente, as concepções de imagem como traço residual da sensação e como elemento associativo do pensamento. No terceiro período, "a imagem deixa de ser interpretada como prolongamento da percepção e tende a adquirir o status de um símbolo" (p. 71). A este período correspondem às questões teóricas a respeito do simbolismo, levantadas pela psicanálise e suas dissidências.

Sobre a questão de saber se é ao pensamento típico da criança ou ao arquétipo do inconsciente coletivo que se deve atribuir a gênese das imagens simbólicas - ou formas recorrentes de imaginar -, Piaget e Inhelder consideram a primeira hipótese mais parcimoniosa do que a teoria junguiana das imagens arquetípicas e do inconsciente coletivo. Entretanto, uma terceira via para abordar essa questão é buscar na própria imaginação e em seus dinamismos a resposta para verificar como a imaginação imagina. Ou seja, buscar na própria atividade imaginativa seus princípios organizadores e sua gênese, como o fez Bachelard (1960/1988) e, posteriormente, Durand (1980/1989). Este último, procurando estabelecer as bases motivacionais da gênese do simbolismo, adota a noção de arquétipo deixando de lado aquilo que a explicação junguiana tem de conceitualmente frágil: uma concepção biológica segundo a qual a imagem simbólica é derivada da pulsão.

Durand (1980/1989) desenvolve em As estruturas antropológicas do imaginário uma topografia do imaginário avessa às reduções sociológicas e psicológicas da imagem ou, em uma expressão do autor, um jardim das imagens primordiais da espécie humana. Seu trabalho representa também um desenvolvimento da noção junguiana de arquétipo e um projeto de sistematizar aquilo que a teoria junguiana deixou em aberto, ou seja, uma terminologia precisa acerca da imagem e do imaginário e uma arquetipologia geral. Em relação a esta última, Durand distingue dois regimes de imagens, o diurno e o noturno. O primeiro é caracterizado pela antítese polêmica das estruturas heróicas, cuja simbólica se expressa pela distinção e oposição entre os símbolos, por um lado, teriomorfos, nictomorfos, catamorfos, e, por outro lado solares, ascensionais e espetaculares. O segundo regime da imagem - noturno - é caracterizado, ao contrário, pela simbólica da intimidade, do aprofundamento e da penumbra das estruturas místicas ou pela simbólica historicizante, progressista ou cíclica das estruturas sintéticas. Os símbolos, os arquétipos e os sistemas conceituais da cultura humana são organizados, segundo esses eixos imaginais que são os regimes e as estruturas do imaginário, estas últimas definidas por Durand como "protocolos normativos das representações imaginárias, bem definidos e relativamente estáveis" (1980/1989, p. 44). Dessa forma, as imagens simbólicas são interpretadas a partir das relações que estabelecem entre si, de seu arranjo e convergência em torno de uma determinada estrutura. Assim, a imagem do fogo pode ser tanto um símbolo de intimidade e de aconchego quando é o calor que aquece uma cabana ao cair da tarde (estruturação mística), quanto um símbolo diurno quando é a arma de ataque do herói contra um monstro devorador (estruturação heróica). $\mathrm{Ou}$ ainda um símbolo de iniciação, quando é a brasa que queima o corpo do neófito durante o ritual de passagem (estruturação sintética).

Tem-se então, como acima mencionado, uma arquetipologia sem a concepção pulsional do arquétipo, o que não implica em excluir aquelas imagens cuja gênese seja pulsional, mas em não situar nas pulsões a gênese das imagens em geral. Neste sentido, a relação entre imagem e pulsão não é uma relação causal. A imagem é que iridesce o passado e seu campo é o halo de sua repercussão, ou seja, o imaginário. Um exemplo: Sr. José, de noventa e quatro anos de idade, possui um estilo peculiar de contar suas histórias. Ao descrever, certa vez, um pé-de-café, o ancião olhava o vazio à sua frente como se estivesse a planta, apontando em sua direção, descrevendo sua "anatomia" e o local preciso onde uma poda deveria ser feita. Durante o relato, era possível sentir a presença viva da imagem diante dele: o pé-de-café estava ali, materializado.

Durand (1980/1989) parte de uma concepção simbólica da imaginação, o que significa que admite uma semântica das imagens, ou seja, que essas diferem dos signos por "conterem materialmente, de algum modo, o seu sentido" (p. 41). Ele postula, assim, uma relação de continuidade entre razão e imaginação, chegando a definições bastante claras de signo e símbolo. Segundo o autor, a consciência dispõe de duas maneiras básicas de representar o mundo: a primeira, representação direta, dá-se através da percepção na presença do objeto; a segunda, representação indireta, ocorre na ausência do objeto e por meio de uma imagem. Tem-se, assim, um contínuo, onde a consciência dispõe de diferentes graus da imagem, cujos dois extremos seriam constituídos "pela adequação total, a presença perceptiva ou a inadequação mais acentuada, ou seja, um signo eternamente privado do significado, e veremos que esse signo longínquo nada mais é do que o símbolo" (Durand, 1964/1988, p. 12).

Se Durand (1980/1989) não adota, como foi visto, uma concepção pulsional do arquétipo, qual seria, então, o seu modelo explicativo para as imagens inatas? É particularmente interessante em sua teoria a proposta de buscar em uma 
ordem de coisas mais simples, mais visíveis e antropologicamente palpáveis, o princípio organizador de sua "geografia das imagens". O que há de mais simples e universal do que os reflexos fundamentais para uma determinada espécie? Em As estruturas antropológicas do imaginário (1980/1989) ele identifica as noções de gesto ou dominante reflexa como as matrizes elementares sobre as quais o recém-nascido - e a espécie humana - constroem, progressivamente, o simbolismo. Essas matrizes são para Durand os eixos em torno dos quais se polarizam as estruturas antropológicas do imaginário - verdadeiros "nós imaginais" que organizam os símbolos, seja a nível individual ou coletivo. Dito de uma outra maneira, as dominantes reflexas:

Não são outra coisa senão os mais primitivos conjuntos sensório-motores que constituem os sistemas de 'acomodações' mais originários na ontogênese e aos quais, segundo a teoria de Piaget, se deveria referir toda a representação em baixa tensão nos processos de assimilação constitutivos do simbolismo (Durand, 1980/1989, p.34).

A noção gesto ou dominante reflexa é extraída por Durand (1980/1989) da reflexologia russa de Betcherev. Este, segundo Durand, identifica no recém-nascido três gestos ou dominantes reflexas: (a) dominante de posição ou postural, relacionada à verticalização do corpo e à organização óculo-motora; (b) dominante de nutrição, que se manifesta no recém-nascido pelos reflexos de sucção labial e de orientação correspondente da cabeça, deglutição e defecação; (c) dominante copulativa, relacionada à rítmica vital e à sexualidade (conforme citado por Durand, 1980/1989). Aos gestos inconscientes das dominantes reflexas correspondem, em uma espécie de convergência semântica, as representações constitutivas do imaginário. Dessa forma, à dominante postural correspondem os esquemas da verticalização ascendente e da divisão manual ou visual; à dominante digestiva correspondem os esquemas da descida, do acocoramento na intimidade e do esconderijo; à dominante copulativa correspondem os esquemas rítmico, dialético e progressista. Tendo como referência a terminologia de sua teoria do imaginário, a essas dominantes reflexas correspondem, segundo Durand (1980/1989), respectivamente, as estruturas heróica, mística e sintética do imaginário.

\section{Do heroísmo negativo a um heroísmo descontraído}

Tomando como ponto de partida a arquetipologia de Durand (1980/1989) com a finalidade de analisar as imagens presentes na literatura científica sobre o envelhecimento, pode-se verificar que essas imagens são, geralmente, de uma simbólica descensional, catamórficas e nictomórficas, no qual o ego do ancião é vencido ou rendido gradualmente pelas formas monstruosas (somáticas e psíquicas) da demência. O imaginário heróico ocidental, ao voltar-se sobre o envelhecimento, só pode encontrar, do ponto de vista lógico, a derrota, por operar segundo um princípio de explicação esquizomorfo baseado em antítese, exclusão e contradição, no qual a demência a ser combatida ou atenuada deve, por fim, vencer o herói. A estrutura simbólica da grande maioria dos artigos científicos sobre o assunto são, empregando a expressão do psicólogo Yves Durand (1988), formas negativas de heroísmo.

$\mathrm{Na}$ Psicologia, as imagens acerca da velhice - e os sistemas conceituais a elas correspondentes - são também descensionais e reforçam as imagens ou preconceitos da gerontologia "por meio de suas concepções clássicas sobre a periodização da vida e sobre a determinação genéticobiológica do envelhecimento, o qual teria um curso idêntico para todos os seres humanos caracterizado por perdas biológicas e psicossociais irreversíveis" (Neri \& Nogueira, 1994, p. 55).

A partir da década de 90, em uma tendência que permanece até os dias de hoje, presencia-se uma alteração no tipo de imagens que a literatura científica vem se valendo quando descreve a velhice. Pode-se observar que o heroísmo-negativo referido inicialmente foi substituído por um heroísmo-descontraído, ou seja, por imagens em que geralmente o herói está em repouso e o monstro afastado a uma distância segura. Mas qual o significado psicológico e cultural dessa mudança? Por um lado ela representa um desenvolvimento na representação social da velhice, nas experiências mais fecundas de envelhecimento e no incentivo de programas comunitários voltados para a terceira idade, tais como universidade para a terceira idade. Em contrapartida, o heroísmo descontraído pode assumir uma forma supersticiosa, na qual o velho mantém a angústia (com suas monstruosidades) a uma distância segura por meio da ritualização (exercícios, dietas e atividades). Dessa forma, suprimir o confronto ou preparar-se para ele resultaria, em última análise, ainda na derrota. Um heroísmo, portanto, que longe de lidar com o conflito diretamente, procura exorcizá-lo com o auxílio da mídia e do mote da "melhor idade", ou mantê-lo a uma distância segura, onde:

São considerados seres problemáticos que necessitam de motivação, os aposentados e velhos que não se empenham em desenvolver uma nova carreira ou um novo conjunto de atividades de lazer ou, ainda, que não se envolveram ativamente em programas de manutenção corporal (Debert, 1996, p. 9-10).

Em uma outra direção, a concepção de envelhecimento vem passando por revisões na psicoterapia, campo privilegiado no qual as perspectivas de desenvolvimento da personalidade podem ser atualizadas e observadas. Se a abordagem junguiana foi pioneira ao reconhecer abertamente o princípio de que o idoso continua a se desenvolver emocionalmente e a realizar seus potenciais, existe hoje uma crescente adesão a essa idéia e prática. $\mathrm{O}$ desenvolvimento da personalidade 
envolve outros aspectos além daqueles diretamente relacionados ao desenvolvimento do ego e da cognição. Não se trata aqui de subvalorizar os aspectos cognitivos, mesmo porque tem-se verificado que durante o envelhecimento saudável existe mais estabilidade do que declínio intelectivo (Lambrechtsen, 1976) e que uma lentificação das funções motoras, sensoriais e psíquicas (Seltzer, 1986) é o que parece caracterizar o envelhecimento. Messy (1992) faz desmoronar a noção de que exista um padrão homogêneo de funcionamento mental na velhice "com traços de caráter específicos ou com o ego organizado de uma maneira particular" (p. 21). Em outras palavras, segundo a autora, "a pessoa idosa não existe"! E mais: "a medicina, através da geriatria, que a seguiu, apropriou-se da gerontologia, atribuindo as queixas à idade e não à angústia." (p. 27). Alinhado a esse pensamento, Gerard Le-Goues (1984) conclui que o processo destrutivo durante o envelhecimento "pode ser prevenido em pacientes que continuam a usar seu poder mental para brincar" (p. 1259). Já Settlage (1996) relata a psicanálise de uma anciã centenária, na qual a presença da criatividade "foi uma parte crucial da habilidade da paciente para manejar, transformar e transcender as perdas da velhice" e conclui: "embora o vigor físico diminua com a idade, a intensidade da mente inconsciente continua atemporalmente intacta" (p.559). Trabalhos como esses colaboram para a demolição do mito, sistematicamente questionado a partir da década de oitenta, da inviabilidade do tratamento psicoterápico para os idosos, em especial para os anciões, pois "a idade cronológica por si mesma não é um índice da conveniência da psicanálise" e "o processo analítico terapêutico não está relacionado à idade" sendo "o mesmo no ancião ou no paciente mais jovem." (idem, 1996, p. 558).

Uma questão relevante na investigação e no acompanhamento profissional do ancião é quanto à forma mais apropriada para abordar a sua organização psíquica e sua personalidade, especialmente quanto ao papel da imagem e da imaginação simbólica. O objetivo desse estudo é, nesse sentido, investigar as imagens simbólicas produzidas por nonagenários e analisá-las segundo a hermenêutica proposta por Durand (1980/1989) em As estruturas antropológicas do imaginário, verificando a propriedade e o alcance desse modelo no estudo do envelhecimento.

\section{Método}

Embora tenha sido desenvolvido há aproximadamente 12 anos atrás (Migliorini, 1999), o presente estudo mantém sua atualidade e relevância, pelos seguintes motivos: (a) o número de longevos tem aumentado nos últimos anos e o prognóstico é de que continue a crescer consideravelmente, a ponto de existirem no Brasil atualmente serviços ambulatoriais e de assistência residencial especializados no atendimento aos nonagenários; (b) ainda predomina na literatura especializada, conforme já foi assinalado, a investigação dos aspectos cognitivos do envelhecimento e; (c) embora na última década tenha crescido no Brasil o número de estudos sobre o imaginário do envelhecimento segundo o modelo durandiano (Sequenzia, 2002; Cardoso, 2005; Santana \& Santos, 2005; Terra, 2007; Loureiro, 2004, 2008a, 2008b), esses trabalhos não estão voltados especificamente para a longevidade e os longevos.

Nas próximas seções, será apresentado de forma sintética o material coligido durante as entrevistas realizadas com três anciões nonagenários.

\section{Participantes}

Os participantes foram escolhidos tendo por base os seguintes critérios: (1) faixa etária acima de noventa anos, (2) ausência de um quadro de demência senil do tipo arteriosclerótica (serem anciões clinicamente saudáveis), (3) serem ativos socialmente e (4) participação voluntária. Eles foram recrutados a partir de um contato prévio com uma assistente social asilar e por meio de uma rede informal de conhecimento do pesquisador através de vizinhos, amigos, profissionais do seu círculo de relações. Como o estudo foi desenvolvido em duas cidades interioranas do centro-oeste do Estado de São Paulo durante aproximadamente dezoito meses (período compreendido entre o contato inicial com os possíveis participantes e a realização das entrevistas), o número de selecionados foi definido de acordo com as dificuldades de se encontrar anciões que atendessem a todos os critérios de seleção mencionados acima.

Os participantes foram: Sr. Ângelo (noventa e cinco anos), Dona Lili (noventa e nove anos) e Sr. José (noventa e quatro anos).

\section{Procedimento}

Os participantes foram acompanhados durante um período que variou de dois meses (Sr. Ângelo) a oito meses (Dona Lili), em encontros semanais de aproximadamente trinta minutos a uma hora de duração, que ocorreram nos seus locais de moradia. Sr. Ângelo mora só, Sr. José com a família e Dona Lili em seu apartamento, em uma pensão asilar.

O limite temporal definido em oito meses teve por finalidade: (a) minimizar possíveis transtornos na rotina familiar ou asilar; (b) prevenir possíveis danos afetivos no momento da interrupção do vínculo, caso o estudo se prolongasse por períodos mais extensos. Nessas ocasiões, foram realizadas entrevistas abertas, gravadas sempre com o consentimento dos anciões e quando não constituíssem um transtorno para os mesmos. As entrevistas tinham por objetivos coligir material de natureza simbólica, como estórias, grafismos, sonhos, devaneios ou lembranças, conforme a preferência de cada participante.

Os participantes foram esclarecidos quanto aos objetivos da pesquisa e aos cuidados éticos a serem tomados em relação ao sigilo de suas identidades, preservadas através de nomes fictícios. Neste sentido, os mesmos esclarecimentos foram dados aos familiares de Sr. José e à assistente social da pensão asilar onde vivia Dona Lili, já que esta não possuía nenhum parente próximo na época em que foi realizada a pesquisa. 
Durante as entrevistas, foi colocado à disposição dos anciões material gráfico do tipo lápis comum, lápis de colorir e papel sulfite. Nas entrevistas iniciais, o Arquétipo-teste a nove elementos (AT.9) foi proposto como atividade a cada um dos participantes, mas apenas um deles concordou em realizar a prova. O AT.9 foi desenvolvido na década de sessenta pelo psicólogo Yves Durand (1988) com a finalidade de verificar empiricamente a teoria do imaginário de Gilbert Durand (1964/1988, 1980/1989). O procedimento não tem por princípio uma teoria projetiva, mas uma classificação compreensiva das imagens, ou seja, não está atrelado a uma teoria psicodinâmica em específico. O AT.9 é uma prova de imaginação a partir de nove palavras-chaves (uma queda, uma espada, um refúgio, um monstro devorante, alguma coisa cíclica, um personagem, água, um animal e fogo). Ele prevê a realização de um desenho, seguido de uma estória e, finalmente, um questionário No Brasil, Loureiro (1993) foi pioneira na utilização do AT.9 com idosos ao investigar o imaginário de um grupo de professores sexagenários aposentados, do Distrito Federal. A autora tem se dedicado, desde então, ao estudo do envelhecimento por meio do AT.9 (Loureiro, 2004, 2008a, 2008b), embora seus trabalhos não focalizem especificamente o grupo dos nonagenários.

\section{Análise dos dados}

O método utilizado para a análise dos dados consiste em identificar na produção de cada um dos participantes as imagens simbólicas predominantes, as relações que elas estabelecem entre si e seu arranjo e convergência em torno de uma determinada estrutura do imaginário. Nesse sentido, a finalidade é aplicar o método de interpretação criado por Durand (1980/1989) à análise das imagens simbólicas produzidas, investigando as estruturas do imaginário prevalentes, assim como suas as organizações psíquicas dos anciões participantes e o papel da imaginação simbólica na velhice.

\section{Resultado e Discussão}

\section{Sr. Ângelo e os devaneios do vôo ascensional}

Embora as imagens descensionais sejam correntes no imaginário da ciência acerca do envelhecimento, elas não são necessariamente recorrentes no imaginário dos próprios idosos. Uma simbólica heróica do tipo ascensional foi encontrada em ativo funcionamento nas falas do Sr. Ângelo, ancião de 95 anos lúcido, participativo e respeitado pela comunidade onde vive. Ativo, esse nonagenário de olhos meigos e brilhantes organiza palestras, sessões de passe e aconselhamento espiritual, sendo admirado e muito requisitado para essas atividades.

O imaginário de Sr. Ângelo está repleto de símbolos ascensionais, imagens heróicas de aperfeiçoamento moral e espiritual. Em duas, de uma série de três entrevistas (realizadas entre março e abril de 1996), ele repete a seguinte máxima: "Educar é transformar a irracionalidade em inteligência, a inteligência em humanidade e a humanidade em angelitude", completando: "todos seremos anjos, todos caminhamos para ser anjos... uns demorarão mais, outros menos, mas todos seremos anjos!".

$\mathrm{O}$ anjo, símbolo ascensional, inscreve-se no regime diurno das imagens no qual, segundo Durand (1980/1989, p. 102), "a imaginação tinge-se de um matiz ascético que faz do esquema do vôo rápido o protótipo de uma sublimação da carne e o elemento fundamental de uma meditação da pureza".

Sr. Ângelo é um verdadeiro "pedagogo do imaginário", um aglutinador de símbolos de elevação para os combalidos - o que possivelmente explica a tônica educativa em suas respostas ao longo de nossas entrevistas. Consultado a respeito de como se atingir a velhice de forma saudável, ele afirma que "a conquista da paz é conquista dos fortes!". Em um mundo repleto de dores psicológicas, o método a ser empregado pelo ser humano é o de "opor aos defeitos as virtudes", primeiramente através de "um exame dos nossos senões (...) de nossas imperfeições mais sérias", seguido de uma oposição à nossa "animalidade", ao nosso "temperamento". Esse caminho para o desenvolvimento moral é árduo e "mais difícil que o desenvolvimento intelectual ou cultural, pois trazemos conosco taras milenares".

É notável o seu heroísmo de inspiração muito mais afetiva do que guerreira, onde as armas são os sentimentos sublimados. Um heroísmo de inspiração angélica - pois "qualquer anjo é um pouco militar" (Durand, 1980/1989, p. 94), de reação à queda imaginária e à animalidade atávica. Solicitado a dar uma mensagem a outros idosos sobre como envelhecer bem, Sr. Ângelo novamente prescreve o imaginário da ascensão: "Consolar, levantar o ânimo e com idéias altruístas. A mente é criadora, formule o que deseja e isso vai acontecer".

Enfim, é possível vislumbrar uma via aproximativa entre o cultivo destas imagens ascensionais por Sr. Ângelo e o método psicoterápico criado por Robert Desoille (1971), o rêve eveillé dirigé, que consiste em estimular devaneios verticalizantes e ascendentes, promovendo, desta forma, uma verdadeira pedagogia da imaginação - tal como a visualisada no papel terapêutico e pedagógico espontaneamente desempenhado por esse ancião-conselheiro e presente em suas imagens estimadas do anjo e do lento vôo do desenvolvimento moral e espiritual, como ato humano, por excelência.

\section{As casas de Dona Lili}

Dona Lili é uma velhinha de noventa e nove anos de idade, simpática, afetuosa, bem humorada e muito estimada pelos funcionários e residentes da pensão asilar, onde vive há aproximadamente cinco anos. É culta, gosta de ler (uma de suas distrações é a leitura de um dicionário da língua portuguesa), fala e escreve o português de forma correta, com vocabulário rico e construções gramaticais precisas - muito embora tenha freqüentado apenas "um ano de escola". É magrinha, de baixa estatura e lépida: no período das primeiras entrevistas, ia e voltava ao centro da cidade sozinha a pé ou 
de ônibus; freqüentava missas e fazia suas compras. Segundo a assistente social asilar ela ainda participava ativamente das atividades sociais e de lazer da instituição e há anos não visitava um médico. Foi costureira e, por esse motivo, ainda fazia pequenos consertos de roupas quando lhe pediam. Recentemente, requisitou a uma das funcionárias um serviço qualquer, por "não agüentar ficar sem fazer nada". Entretanto, suas condições de saúde após uma fratura do fêmur alteraram consideravelmente sua rotina durante o período final da pesquisa.

Durante um período de aproximadamente oito meses, em entrevistas semanais (realizadas entre agosto de 1996 e março de 1997), Dona Lili produziu uma série de desenhos com o tema da casa de sua infância. Embora não se possa classificar essas produções como espontâneas no sentido exato da palavra, elas foram, em sua maioria, realizadas a sós e sem incentivo direto - algumas delas feitas por iniciativa própria, sem solicitações de execução e, presume-se, com o material disponível no momento: papel de presente usado, verso de panfletos e restos de papel (lápis comum, lápis colorido e papel sulfite eram regularmente colocados a sua disposição). As casas, casinhas e casarões que Dona Lili desenhou são imagens estimadas, cultivadas, reconfortantes e marcam o tom de intimidade e aconchego fundamentais das estruturas místicas do regime noturno das imagens, cujos arquétipos principais são o profundo, o calmo, o escondido, o quente, o íntimo e cujas substantificações, por excelência, são a moradia, a casa, o refúgio.

Cabe lembrar ainda que Dona Lili participou de quatro aplicações do Arquétipo-teste a nove elementos (AT.9), as quais, juntamente com a série completa de grafismos sobre a casa natal, foram assunto de um outro estudo (Migliorini, 2004). Também nessa produção predomina uma estruturação mística das imagens simbólicas. Por exemplo, na primeira aplicação do AT.9, Dona Lili desenha os elementos-estímulo refúgio e monstro-devorante, como duas figuras praticamente idênticas, exceto pelo tamanho. Os desenhos, segundo ela, representam duas casas, sendo a menor, a casa do personagem ou seu refúgio. A casa maior representa o monstro-devorante, uma "casa monstruosa" ou simplesmente a "casa do monstro". Ao mesmo tempo Dona Lili se refere à casa maior como uma cômoda, na qual se pode "guardar tudo que se tem". Observa-se, portanto, uma espécie de fusão semântica entre essas representações da casa, suas funções e simbolismos, que assumem um aspecto ora negativo, ora positivo. Trata-se de uma casa comum e de uma casa monstruosa, onde podem se refugiar, respectivamente, personagem e monstro. A eufemização encontrada na imagem do monstro e o encaixamento sugerido pelo par de casas (e também pela imagem da cômoda), bem como a suavização ou a eliminação das contradições de todo o conjunto, são típicas das estruturas místicas do imaginário. O conjunto perde em nitidez, tornando-se um tanto borrado, em uma espécie de fusão também das formas ou de misticismo atualizado através das formas. Cabe assinalar que um processo semelhante de fusão ou síntese entre duas matrizes cognitivas foi descrito por Koestler (1967) como sendo a "essência do ato criativo" (p.330).

\section{"O rio de ciência" ou "A cachoeira encantada"}

Se as imagens de Dona Lili e os devaneios ascensionais de Sr. Ângelo ilustram respectivamente as estruturas mística e heróica do imaginário, algumas das estórias de $\mathrm{Sr}$. José serão aqui apresentadas como próprias da estrutura sintética. Sr. José tem sobre um móvel de sua sala, um ninho de joão-de-barro que ele retirou de uma árvore anos atrás e relembra que passava horas observando como o bichinho fazia para construí-lo. Embora o ancião não se sentisse à vontade ou familiarizado com desenhos e preferisse contar estórias, nesse dia ele assentiu e desenhou um pequeno joão-de-barro. Num mesmo pedaço pequeno de papel, ele faz três esboços do pássaro, um ao lado do outro, em uma seqüência que sugere um alçar vôo. O pássaro aqui não é um símbolo ascensional como o anjo guerreiro, mencionado por Sr. Ângelo, mas um símbolo da intimidade, do aconchego doméstico e da fragilidade pulsante que invoca a proteção de um ninho. Trata-se de um pássaro inscrito no regime noturno das imagens.

O manejo de papel e lápis está associado à escolaridade e Sr. José parecia sentir-se um tanto inferiorizado nesse aspecto, pois não teve acesso aos estudos. Enquanto desenhava, dizia algo como "vou ver se ela [filha] faz" ou "vou ver se minha filha faz pra mim". Inicialmente, afirmou que não saberia como fazer o desenho solicitado. Na seqüência, começou a contar uma estória da época em que tinha nove anos de idade e de como aprendera a carpir e fazer a poda do cafezal. Em uma certa fazenda, havia uma plantação de café tomada pelo mato que ele acertara com o proprietário para carpir. Para isso, contratou dois ajudantes experientes, pois ele mesmo, criança, não sabia como dar conta do serviço. Cada um dos três passou, então, a carpir uma rua de café. A do menino foi colocada estrategicamente entre as ruas dos ajudantes, para que ambos pudessem auxiliá-lo: quando o menino ficava para trás, os outros dois carpiam furtivamente um tanto da rua central, até que os três estivessem no mesmo nível. E faziam isso sem humilhar o garoto, cuidando de seus ferimentos quando ele se cortava com as ferramentas e o incentivando. Era enternecedor o sentimento de camaradagem que surgia ao longo de seu relato.

Parece significativo o fato de Sr. José dar início à sua estória justamente no momento em que lhe era solicitada uma tarefa para a qual não se sentia preparado. Haveria uma ligação implícita entre a rua de café a ser carpida por um menino despreparado e a realização da desafiante tarefa de desenhar? Entre os ajudantes camaradas e um possível auxílio de sua própria filha na realização do desenho? Ou ainda entre o entrevistador e o dono do cafezal, que lhe encomendaram tarefas difíceis de realizar?

Cearense, nascido em 1902, Sr. José veio com a família para o interior de São Paulo aos oito anos de idade e se 
instalou no campo, onde aprendeu o plantio e a colheita do café. Dada a sua iniciativa, em pouco tempo passou à função de capataz. Trabalhou arduamente em empreitadas, chegando a liderar 70 homens de uma só vez para o plantio de café. $\mathrm{Na}$ ocasião, seu patrão tinha o sugestivo nome de Coronel Fadiga. Além de colono, empreiteiro, trabalhou como ambulante e vendedor de peixes. Foi vicentino por dez anos, cuidando de algumas famílias (praticamente adotando uma delas), fornecendo alimentos, ajuda na área de saúde, moradia e educação. Atualmente Sr. José vive com uma das filhas e netos, sendo um homem respeitado pela família e conhecido na vizinhança por sua lucidez e "bom papo".

Durante um período de aproximadamente sete meses ele participou de uma série de entrevistas semanais, realizadas em sua casa (entre junho e dezembro de 1996) e relatou algumas de suas estórias. Sr. José tem um estilo peculiar de contá-las, fazendo uso da repetição - tanto dos conteúdos das estórias, como das próprias estórias. Em uma das entrevistas, ele segredou a respeito de um certo "rio de ciência" que conheceu, o qual também denominava muitas vezes como "cachoeira encantada". Tinha "de sete para oito anos mais ou menos" quando tudo aconteceu. Essa estória foi gravada durante uma das entrevistas e parte de sua transcrição literal é reproduzida abaixo.

Ali era uma cachoeira encantada que ninguém quase sabia e esse rapaz muito conhecido, foi e me informou, que tinha essa cachoeira, que eu ia passar nela (...) e se fizesse assim uma experiência nela, que eu ia ver que ela era encantada mesmo. Ele disse: - Você pega seu chapéu... O chapéu era daquele cipó que fazem cadeira (...) era de um cipó que eles trançavam e faziam chapéu para vender, mas eu não estou lembrado desse cipó o nome dele; era duro que era uma coisa enorme, que nem pau. (...) Usava muito daquele chapéu. Pegava-se ele, jogava ao ar livre, assim, ele batia lá [na cachoeira] que nem um pedaço de pau. (...) E eu comprei, achei muito bonito esse chapéu e comprei um e disse: - Eu vou passar por essa cachoeira e vou tirar essa experiência (...). Eu vou ver se é verdade. Quando eu estava na frente da cachoeira... A cachoeira é um rio que passa por cima (...) cai ali em baixo e fica como quem está fervendo, né... a água. E tratam a cachoeira de cachoeira encantada. (...) Tirei aquele chapéu (...) e joguei no meio da cachoeira. Digo: - Isso é verdade mesmo, você vai jogar o seu chapéu e vai notar bem que o seu chapéu vai voltar no mesmo lugar. (...) E assim, conforme eu joguei, o chapéu foi virando, virando, virando, chegou lá na cachoeira, ele fez uma paradinha...lá veio voltando pra trás, veio voltando, veio onde eu estava de pé.

A estrutura formal é cíclica, assim como os seus elementos (o chapéu e água da cachoeira). Há no relato uma repetição por vezes incômoda para a leitura, mas que é um recurso expressivo impressionante para o ouvinte. Essa estrutura pode ser resumida em duas palavras: hipotipose e pontilhamento da imagem que, nesse caso, podem ser compreendidas como um modo de retratar a imagem e não simplesmente como dificuldade de articulação e de expressão dos pensamentos decorrente da idade avançada. A historicização e esse caráter cíclico (progressismo) são típicos do regime noturno das imagens, das estruturas sintéticas do imaginário e, dentre essas, da estrutura histórica, ou seja, de "uma estrutura que já não tenta - como a música ou a cosmologia - esquecer o tempo, mas que, pelo contrário, utiliza conscientemente a hipotipose que aniquila a fatalidade da cronologia" (Durand, 1980/1989, p. 240).

Durand (1980/1989) demonstrou como a viscosidade e a repetição detectadas no teste de Rorschach não são nada mais que a presença de um regime de imagens predominante. Da mesma forma, o relato sobre o pé-de-café mencionado anteriormente, seja por seu aspecto cíclico-vegetal, seja pela maneira como é minuciosamente retratado, é uma imagem que se inscreve no regime noturno do imaginário. Um último exemplo surpreendente de estruturação sintética das imagens nas narrativas de Sr. José é o caso do hobbie incomum de seu irmão mais novo. Este se empenha há muitos anos em construir - projetando peças sob medida e em um compartimento especialmente dedicado a esta finalidade - uma máquina de ciclo perpétuo. O lendário moto-contínuo.

Os estudos sobre o imaginário de idosos indicam que há uma tendência das imagens simbólicas organizarem-se segundo o regime noturno de imagens, especialmente em torno das estruturas místicas (Durand, 1988). Entretanto, no conjunto das imagens desse grupo de anciões não foi encontrado um regime de imagens recorrente. Ao contrário, cada um de seus integrantes organiza as imagens simbólicas, marcadamente, segundo distintas estruturas do imaginário: identificadas nos devaneios heróicos de Sr. Ângelo, no imaginário sintético das estórias contadas por Sr. José e nas imagens místicas de Dona Lili. Não se trata aqui de visar uma categorização, pois todo imaginário humano é articulado por estruturas "irredutivelmente plurais" (Durand, 1994, p.26), que se interpenetram. O heroísmo de Sr. Ângelo e as lembranças de Dona Lili, por exemplo, apresentam imagens potencializadas de uma estruturação sintética, enquanto as estórias de Sr. José apresentam uma coloração francamente heróica. As imagens simbólicas de cada um desses anciões, entretanto, convergem e organizam-se em torno de uma determinada estrutura do imaginário.

Os resultados indicam, portanto, que a idéia de uma tendência ou prevalência na estruturação das imagens simbólicas durante o envelhecimento merece ser revista. Essa discussão pode ser enriquecida considerado que o grupo estudado foi composto por anciões clinicamente saudáveis ou, usando termos do vocabulário popular (e por que não imaginário popular) anciões "lúcidos" ou que "envelheceram bem". 
Outro aspecto relevante é que também o heroísmo negativo e o heroísmo descontraído, identificados nas imagens da literatura científica sobre o envelhecimento, não foram detectados na estruturação das imagens dos anciões estudados.

Em relação à organização psíquica, o que é notável nesses três anciões e, certamente, um traço comum entre todos eles, é a presença de uma intensa vida imaginativa - apesar de seus processos mnêmicos, muitas vezes, sofrerem uma alteração. Embora a memória de Sr. José para fatos passados esteja bastante preservada, ela enreda-se à imaginação de tal forma que muitas vezes subordina-se a esta última. Um exemplo: seu pai era dono de uma propriedade agrícola no nordeste e, como uma parenta próxima era cangaceira, dava eventualmente refúgio e guarida aos homens de Lampião. Uma prática comum entre os cangaceiros era o treino de pontaria, que podia ter um tom lúdico ou iniciático-guerreiro: aquele que errasse o alvo deveria ser "carimbado" com um golpe de faca em um local do corpo escolhido de antemão por seu desafiante. Antonio Silvino, freqüentador assíduo da fazenda de seu pai, arrancou certa vez a orelha de um "neófito" que errara o alvo vezes seguidas e, como seu punhal estava sem corte, a orelha do peão foi cortada, segundo expressão de Sr. José, no "calor do punhal". Estórias como estas eram contadas em inúmeras variações. Certa vez, comentando sobre a pontaria da companheira de Lampião, Sr. José iniciou imediatamente um relato, muito semelhante ao anterior, tendo agora Maria Bonita como protagonista. De fato, havia pouca diferença entre a primeira estória e a segunda: a imaginação, neste caso, recriou o passado sem comprometer a verossimilhança.

A memória de Dona Lili para fatos recentes, por seu turno, vem sofrendo alterações e está bastante reduzida. Dona Lili passou a recordar o nome do pesquisador meses depois do início das entrevistas, entretanto, nunca deixou de identificá-lo. Havia um registro sensorial e emocional, de maneira que sua vida imaginativa e afetiva permaneciam vivas e exuberantes. Esse tipo de "memória afetiva" lhe é peculiar e seus devaneios são povoados por parentes queridos, como pode ser observado através do relato de um de seus únicos "sonhos":

Não sei se sonhei ou se vi mesmo. Estava de pé, muito fraquinho. Não falei nada com ele... acho que era sonho, senão eu perguntava...Vi meu irmão, um altão, desanimado, muito desanimado. Não sei o nome dele... era mocinho... estava tão atrapalhada que não lembro o nome dele.

Observa-se aqui, assim como nas estórias de Sr. José, uma espécie de permeabilidade entre memória e imaginação. Por momentos, torna-se difícil detectar as fronteiras entre ambas, que se articulam de uma forma peculiar e singela. Talvez pelo esmaecimento dessas linhas demarcatórias, afirme Dona Lili a respeito de seus próprios sonhos:

\begin{abstract}
Não sonho mais. Gente da minha idade não sonha mais. Aproveita pra sonhar enquanto é moço. Gente moça sonha muito. Fui percebendo que fui envelhecendo e não sonhava mais. Raramente sonhava.
\end{abstract}

Certas imagens oníricas ou de devaneios podem visar, em princípio, não apenas a realização alucinatória de desejos, mas adaptação à realidade. Esse fenômeno conduz à reflexão de um problema mais abrangente, o do papel espistêmico da imagem na construção das teorias em geral e das teorias psicológicas em particular, assunto investigado por Hillman (1983) e Monzani (1990), que será aqui apenas assinalado. A relação de continuidade entre razão e imaginação simbólica, como a preconizada por Durand (1964/1988), evidencia-se nos conteúdos mentais desses anciões. Os resultados indicam que a imaginação simbólica parece representar um papel significativo no desenvolvimento emocional durante o envelhecimento. Talvez, por isso sejam tão fascinantes alguns desses relatos e, em uma direção semelhante, tenham concluído Mergler e Goldstein (1983) que as mudanças decorrentes do processo de envelhecimento dentro de um contexto social apropriado "fazem dos idosos indivíduos melhor capacitados para realizar certas tarefas, ou pelo menos unicamente capazes de provê-las de forma a incentivar a sobrevivência do grupo, tarefas envolvendo transmissão oral de informações, especialmente nos contextos de contar estórias" (p.78).

Todos os participantes tinham curso primário incompleto e alguns não aderiram de imediato às tarefas do tipo gráfico, como desenhar. Mesmo entre aqueles que se prontificaram a executar as tarefas, havia alguma resistência. Diziam-se incapazes de realizá-las por não saberem desenhar ou por não haverem freqüentado escola. Assim associavam as atividades que envolviam papel e lápis às atividades escolares, para as quais não se sentiam aptos. Talvez, por esse motivo, a entrevista aberta e a observação da imagem através do discurso tenham sido uma forma fecunda de abordar o imaginário nesses casos.

De fato, o nível de escolaridade (que não deve ser confundido com nível cultural) entre a população idosa no Brasil é baixo, sendo esta situação "tanto mais grave quanto mais velhas as coortes” (Berquó, 1996, p. 18). As possibilidades de acesso à educação no início deste século eram bastante desfavoráveis, sendo o sexo e as condições socioeconômicas fatores decisivos de acesso ou interdição. Tais fatores - nível de escolaridade e resistência a desenhar -, entretanto, não impediram que Dona Lili, que freqüentou apenas "um ano de escola", realizasse uma prova complexa como o Arquétipo-teste a nove elementos (AT.9) aos seus 99 anos de idade. Deve-se ressaltar, entretanto, que dentre os participantes, ela foi a única que executou tal façanha.

É possível que essa "preferência" pela palavra falada e o "embaraço" com os grafismos se deva não somente a fatores educacionais e a possíveis limitações de ordem sensorial ou motora, mas a características intrínsecas do próprio 
devaneio de cada um desses anciões em particular. As imagens mais discursivas dos "contadores de estórias", como Sr. José, configuram-se, como foi visto, principalmente na narrativa e no tempo. As imagens mais plásticas e visuais, como as de Dona Lili e Sr. Ângelo, configuram-se privilegiadamente no espaço. As afinidades por um ou outro tipo de imagem, dessa forma, são já indicativas de determinada configuração simbólica.

Finalmente, uma qualidade encontrada em todos nonagenários entrevistados durante o estudo foi a presença de vívidos processos afetivos. Essa qualidade pode ser descrita como preservação da afetividade e uma acentuada expressividade, modulação e comunicabilidade afetivas. Ou ainda, fazendo uso de uma expressão de Maslow (1970), como um "profundo sentimento de identificação, simpatia e afeição pelos seres humanos em geral" (p.165). Exemplificando, com trechos extraídos das entrevistas: Certa vez perguntei ao Sr. Ângelo se ele costumava sonhar e como eram os seus sonhos. $\mathrm{O}$ ancião respondeu afirmativamente, mas logo me dirigiu a resposta em forma de pergunta: E você, sonha? Conte-me algum sonho seu. Contei-lhe, então, um sonho recente, no qual, aparecia subitamente uma garota pedinte durante uma sessão em meu consultório. Irritado, expulsava-a de minha sala. A garota então se vai e o sonho termina. Sr. Ângelo replicou que aquela garota poderia ser um espírito vindo em meu auxílio ou de minha cliente e que eu deveria ouvir a garota, acolhê-la e perguntar o que queria, do que precisava.

Por aí se percebe sua atitude de franca receptividade e brandura para com o outro e para com o desconhecido. Um outro exemplo, é a seguinte atitude de Dona Lili: Certa vez, no momento em que se despedia do pesquisador, ao final de uma das entrevistas, o corredor que conduzia à saída, estava sendo lavado por uma funcionária. A anciã, então, tomou o pesquisador pela mão - apesar dos protestos desse e espanto da funcionária - e atravessou o corredor ensaboado fazendo questão de acompanhá-lo até a saída para que esse não corresse o risco de escorregar.

\section{Considerações finais}

Durand (1964/1988, 1980/1989) fez uma importante contribuição ao estudo da imaginação simbólica e à teoria junguiana ao estabelecer um princípio de relação entre os aspectos filogenéticos, explorados por Jung, e os ontogenéti$\cos$, que buscou na escola de reflexologia russa. Seu método parece apropriado para a abordagem das imagens simbólicas produzidas pelos anciões, na medida em que as interpretações pulsionais podem ser situadas em um espectro mais polifônico e determinados aspectos da experiência destacados. É fundamental, entretanto, contextualizar sua contribuição, pois em As estruturas antropológicas do imaginário: Introdução à arquetipologia geral (1980/1989), obra em que apresenta sua teoria do imaginário, Durand faz referência particularmente à psicologia analítica e à psicanálise freudiana. As hermenêuticas psicanalíticas que não se apóiam exclusivamente em um modelo pulsional de interpretação não são discutidas, como por exemplo a contribuição de Winnicott (1971/1975), que resgata o próprio desenvolvimento ontogenético como chave interpretativa.

Sem pretender uma resposta categórica sobre qual a hermenêutica mais apropriada para o estudo do envelhecimento, o presente estudo procurou ampliar essa resposta, reiterando que a polissemia é o traço fundamental da imagem simbólica. Embora os conteúdos pulsionais sejam indissociáveis da imagem e o anjo, por exemplo, possa ser interpretado como um símbolo da virilidade perdida ou ansiada, o método de Durand possibilitou o acesso a outros aspectos da imagem e da imaginação simbólica. $\mathrm{O}$ anjo de fato funciona como um elemento organizador do psiquismo e da vida social de Sr. Ângelo e o seu significado não se limita a uma pulsão sublimada, embora possa abarcar essa última. De maneira semelhante, pode-se compreender a imagem da casa como um elemento que coloca em movimento questões importantes da vida de Dona Lili e não apenas como um símbolo uterino regressivo.

Em uma outra direção, as imagens simbólicas de cada um dos anciões reportam à infância, seja de forma direta, nas lembranças de dona Lili e de Sr. José, ou indireta, nas referências de Sr. Ângelo à infância da humanidade em evolução. Dessa maneira, símbolos de caráter universal, como a casa originária, o moto contínuo e o anjo guerreiro, parecem estar enraizados em experiências infantis, colocando em questão a gênese das imagens simbólicas. Seriam estas arquetípicas ou típicas da infância? É possível que as experiências ocorridas na infância desses anciões sejam o material sobre o qual se atualizam simbolicamente os conteúdos de natureza filogenética e que os aspectos ontogenéticos e filogenéticos sejam níveis semânticos da imagem que convivem e se sobrepõem (Migliorini, 2008).

Um outro aspecto significativo é que o grupo de anciões estudado não se comportou de uma forma típica no que se refere à imaginação simbólica, seja na prevalência estimada da estruturação mística das imagens simbólicas ou no heroísmo descontraído, como são retratados na literatura científica sobre o envelhecimento. Uma imaginação simbólica exuberante foi encontrada em suas estórias, grafismos, sonhos, devaneios e lembranças, assim como uma permeabilidade entre conteúdos da imaginação e da memória.

As dificuldades com a memória de evocação e fixação não parecem constituir um obstáculo para que vivam de uma forma satisfatória para si mesmos e para o grupo com o qual convivem. Uma afetividade bastante desenvolvida é o traço marcante encontrado em todos os sujeitos. De fato, não seriam a afetividade e a imaginação simbólica mais importante para uma velhice saudável do que a memória, que nesse momento da vida já não desempenha uma função prioritária quanto o 
fazia na infância, na adolescência ou na idade adulta? Diminuir a "nitidez" e a "velocidade" com que se apreende o mundo parece ser uma forma válida e enriquecedora de relacionamento com ele ou mesmo um estilo de organizar as imagens durante o envelhecimento.

\section{Referências}

Bachelard, G. (1988). A poética do devaneio (A. Danesi, Trad). São Paulo: Martins Fontes. (Original publicado em 1960)

Berquó, E. (1996). Algumas considerações demográficas sobre o envelhecimento da população do Brasil. Trabalho apresentado no Seminário Internacional sobre o Envelhecimento Populacional: Uma agenda para o fim do século, Brasília.

Cardoso, V. R. (2005). Velhice asilada, gênero e imaginário. Dissertação de Mestrado não-publicada, Universidade Católica de Brasília, Brasília.

Debert, G. G. (1996). As representações (estereótipos) do papel do idoso na sociedade atual. Trabalho apresentado no Seminário Internacional sobre o Envelhecimento populacional: Uma agenda para o fim do século, Brasília.

Desoille, R. (1971). El caso María Clotilde: Psicoterapia del ensueño dirigido. Buenos Aires: Amorrortu.

Durand, G. (1988). A imaginação simbólica (L. Fitipaldi, Trad.). São Paulo: Cultrix / EDUSP. (Original publicado em 1964)

Durand, G. (1989). As estruturas antropológicas do imaginário: Introdução à arquetipologia geral. Lisboa: Presença. (Original publicado em 1980)

Durand, G. (1994). L'imaginaire: Essai sur les sciences et la philosophie de l'image. Paris: Hatier.

Durand, Y. (1988). L'exploration de l'imaginaire: Introduction à la modelisation des univers mythiques. Paris: L'Espace bleu.

Freud, S. (2002). Três ensaios sobre a teoria da sexualidade. Rio de Janeiro: Imago. (Original publicado em 1905)

Hillman, J. (1983). Healing fiction. Woodstock: Spring.

Jung, C. G. (1973). Collected works of Carl G. Jung. Londres: Routledge \& Kegan Paul.

Koestler, A. (1967). The act of creation. In D. B. Lindsley \& A. A. Lumsdaine (Eds.), Brain function: Brain function and learning (Vol. 4). Berkeley: University of California.

Lambrechtsen, E. (1976). The Myth of the normal intellectual reduction in adults and aged humans. Skolepsykologi, 13, 205-226.

Le-Goues, G. (1984). Aspects de la vie mentale tardive [CD-ROM]. Revue Française de Psychanalyse, 48, 1259-1272.
Loureiro, A. M. L. (1993). Imagens da vida e da morte: Um estudo simbólico-organizacional com idosos. Tese de Doutorado não-publicada, Faculdade de Educação da Universidade de São Paulo, São Paulo.

Loureiro, A. M. L. (2004). O AT.9 e a paisagem mental de um grupo de idosos. In A. M. L. Loureiro (Org.), O velho e o aprendiz: O imaginário em experiências com o AT.9 (pp. 37-62). São Paulo: Zouk.

Loureiro, A. M. L (2008a). A batuta da morte a orquestrar a vida. Interface: Comunicação, saúde, educação, 12, 853-862.

Loureiro, A. M. L. (2008b). Imaginário dos maus tratos com idosos na família: Sofrimento, denúncia, silêncio e desestrutura. In A. M. L. Loureiro, V. Faleiros, \& Penso, M. A. (Orgs.), O conluio do silêncio. São Paulo: Roca.

Maslow, A. (1970). Motivation and personality (2a ed.). New York: Harper \& Row.

Mergler, N. L., \& Goldstein, M. D. (1983). Why are there old people? Senescence as biological and cultural preparedness for the transmission of information [CDROM]. Human Develompent, 26, 72-90.

Messy, J. (1992). A pessoa idosa não existe: Uma abordagem psicanalítica da velhice (J. S. M. Warneck). São Paulo: Aleph.

Migliorini, W. J. M. (1999). Imaginário e envelhecimento. Tese de Doutorado não-publicada, Instituto de Psicologia, Universidade de São Paulo, São Paulo.

Migliorini, W. J. M. (2004). O AT.9 e as imagens simbólicas de uma anciã centenária. In A. M. L. Loureiro (Org.), $O$ velho e o aprendiz: $O$ imaginário em experiências com o AT.9 (pp. 63-84). São Paulo: Zouk.

Migliorini, W. J. M. (2008). O papel da imaginação no desenvolvimento emocional. In M. L. Oliveira (Org.), $O$ acolhimento do desejo na Educação: Um desafio para educadores (pp. 213-227). São Paulo: Cultura Acadêmica Editora / Laboratório Editorial da FCL Unesp.

Monzani, L. R. (1990). A fantasia freudiana. In B. Prado Jr. (Org.), Filosofia da psicanálise (pp. 73-107). São Paulo: Brasiliense.

Neri, A. L, \& Nogueira, E. J. (1994). Como a velhice é apresentada às crianças em textos de literatura infantil brasileira. Pro-Posições, 5(1), 45-60.

Piaget, J., \& Inhelder, B. (1969). As imagens mentais. In P. Fraisse \& J. Piaget (Org.), Tratado de psicologia experimenta (Vol. 7, pp. 71-116). Rio de Janeiro: Forense. (Original publicado em 1963)

Santana, R., \& Santos, I. (2005). Como tornar-se idoso: Um modelo de cuidar em enfermagem gerontológica. Texto \& Contexto- Enfermagem, 14, 202-212.

Sequenzia, V. A. (2002). O imaginário de um grupo de idosos em tratamento de fisioterapia no CRAI/ES: Pistas para a organizacionalidade antropolítica. Dissertação de Mestrado não-publicada, Universidade de Brasília, Brasília. 
Seltzer, M. M. (1986). Timing: The significant common variable in both humor and aging. In L. Nahemow, K. A. McCluskey-Fawcett, \& McGhee, P. E. (Eds.), Humor and aging. Orlando, Fla: Academic Press.

Settlage, C. F. (1996). Transcending old age: Creativity, development and psychoanalysis in the life of a centenarian. International Journal of Psycho-Analysis, 77, 549-564.

Terra, A. P. (2007). O imaginário de um grupo de cuidadores de idosos asilados. Dissertação de Mestrado nãopublicada, Universidade Católica de Brasília, Brasília.

Winnicott, D. W. (1975). O brincar e a realidade (J. O.

A. Abreu \& V. Nobre, Trad.). Rio de Janeiro: Imago. (Original publicado em 1971)

Walter José Martins Migliorini é Professor Assistente Doutor da Faculdade de Ciências e Letras da Universidade Estadual Paulista Júlio de Mesquita Filho, campus Araraquara e supervisor clínico da Universidade Federal de São Carlos.

Recebido: 17/12/2008

$1^{a}$ revisão: 02/04/2009

$2^{a}$ revisão: 06/07/2009

Aceite final: 28/07/2009 